\title{
LOUISE KIELGAST
}

\section{MONTREAL}

De fleste forbinder nok ordet megaby med steder som Shanghai, Tokyo og São Paulo. Disse byer er inden for de seneste årtier eksploderet i omfang og huser i dag et stadig voksende milliontal af mennesker. Megabyen refererer med andre ord typisk til byer med indbyggertal på langt over 10 millioner. I den sammenhæng kan Montreal næppe betegnes som en megaby. Canadas næststørste by tæller, iberegnet et større område af forstæder under navnet Montreal Metropolitan Region, ikke mere end knap 3,3 millioner indbyggere, hvilket gør den til en ganske lille storby sammenlignet med de tre førnævnte. Byen har imidlertid for nylig gennemgået en større centralisering, hvor blandt andet 28 kommuner på øen Montreal er blevet lagt sammen under én storkommune. ${ }^{1}$ I den forbindelse taler canadierne nu om Montreal som en megaby - en betegnelse, som bliver brugt af såvel politikere som borgere. Loven om centralisering, også kaldet bill 170 , blev vedtaget af provinsregeringen i Quebec i december $2000 \mathrm{og}$ er siden trådt i kraft 1. januar 2002, men ikke uden konflikt. Modstanden mod sammenlægningen har været stor og de afstedkomne diskussioner følelsesladede, hvilket jeg erfarede under et feltarbejde i byen i sommeren og efteråret 2001. På baggrund af dette feltarbejde vil jeg vise, at betegnelsen megaby er andet og mere end en neutral typologisering af byen med reference til geografisk størrelse og indbyggertal. I tilfældet Montreal bliver ,,megaby“ synonym med sammenlægningen, og der knytter sig til brugen af ordet megaby vidt forskellige forestillinger om og visioner for Montreal som by, hvilket gør det til en stærkt politiseret term.

Min analyse af kommunesammenlægningen og brugen af betegnelsen megaby vil sætte fokus på byen som et fortolkningsrum, eller med Setha Lows ord ,den omstridte by“ (the contested city) (1999:10,11). Byen, og i dette tilfælde Montreal, er ikke en tilfældig og neutral skueplads, men et symbolsk og politisk rum, hvor forskellige grupper kæmper om indflydelse til at definere og agere.

\section{Et antropologisk blik på kommunesammenlægninger}

Kommunesammenlægningen i Montreal er ikke et enestående tilfælde - den synes nærmere at repræsentere en omsiggribende tendens i Canada såvel som i Europa. ${ }^{2}$ I 1998 foretog Toronto en lignende omstrukturering, som også mødte stor folkelig 
modstand om end ikke i samme omfang og ikke ud fra helt de samme problematikker som i Montreal. Også i Danmark er kommunesammenlægninger et aktuelt emne. Nogle har allerede fundet sted, og mange flere vil følge med strukturreformen. ${ }^{3}$ I forhold til Toronto og Montreal adskiller Danmark sig derved, at der er tale om en strukturreform gældende for hele landet, mens det i Canada drejer sig om at organisere et storbyområde og fordele pligter mellem bykerne og forstæder. Til trods for denne forskel er der også visse lighedspunkter, ikke mindst i måden, hvorpå sådanne strukturelle ændringer typisk bliver diskuteret.

Ligesom det er tilfældet med virksomhedsfusioner, er pengebesparelser og effektivisering hyppigt brugte argumenter til fordel for kommunesammenlægninger - pengebesparelser, fordi unødvendige forvaltningsled forsvinder og dermed også lønudgifter til de ansatte; og øget effektivisering ud fra den betragtning, at større enheder bedre kan løfte visse opgaver. Dermed ikke sagt, at alle favoriserer en sådan løsning, men bemærkelsesværdigt er det, at kommunesammenlægninger ofte reduceres til alene at være et spørgsmål om forvaltning og økonomi. Man taler eksempelvis om strukturelle udfordringer og behov for koordinering (Weber \& Sillasen 2001), eller økonomisk katastrofe (Sancton 2000). ${ }^{4}$ Der synes således at mangle en opmærksomhed omkring de konflikter af mere symbolsk og følelsesladet karakter, der også er til stede i forbindelse med kommunesammenlægninger. Kommunalreformer betyder ikke alene ændringer i forvaltningerne og for disses ansatte, de berører også borgerne i det pågældende område, og debatten i Montreal er et godt eksempel på, at borgerne ikke er passive tilskuere til denne politiske proces. De indgår aktivt, stiller krav og fremfører deres visioner.

I kraft af den store folkelige modstand har borgerperspektivet ikke været fraværende i debatten i Montreal, og der har især været fokus på det demokratiske underskud i sammenlægningsprocessen. Som nævnt blev loven om sammenlægninger vedtaget af provinsregeringen uden først at konsultere den almene borger. I mange kommuner blev der i år 2000 afholdt lokale folkeafstemninger, som viste klare flertal imod loven, men folkeafstemningerne manglede et retsligt grundlag. De var snarere symbolske aktioner og havde ingen indvirkning på regeringen i Quebec City og dens beslutning.

Spørgsmålet om demokrati var således et væsentligt tema, men det politiske spil om kommunesammenlægningen viste sig også gennem ytringer og diskussioner om lokalt tilhørsforhold. Man fornemmede ligefrem, at de kritiske røster om sammenlægningens udemokratiske islæt stod i stærk forbindelse til folks opfattelse af og tilknytning til Montreal som by, og at de fik ekstra næring i kraft af denne forbindelse. Denne artikel vil tage sit udgangspunkt i en af de små kommuner, Montreal West, som nu er en del af et, på papiret, forenet Montreal, og på denne baggrund rejse spørgsmål af såvel generel som specifik karakter: Hvordan har kommunalreformen påvirket beboernes følelse af hjem $\mathrm{i}$ et mindre område af byen? Hvordan tillægges byens administrative grænser social og symbolsk betydning? Og hvad sker der, når disse grænser ændres?

Interessen for samspillet mellem planlægning og bypolitik på den ene side og borgernes reaktioner på den anden side udgør et væsentlig felt inden for byantropologi (Caldeira 1999; McDonogh 1999; Abu-Lughod 1994), som ofte fokuserer på politikkers uheldige konsekvenser for byens i forvejen marginaliserede. I Montreal West er den typiske beboer både veluddannet og velhavende. Montreal West'erne har ikke formået at ændre lov 170, men de har, ikke mindst i kraft af deres mange ressourcer, været aktive medskabere af visioner for såvel hele byen som for deres egen bydel. Montreal 
West er et lille område på ca. 160 hektar og tæller kun lidt over 5.000 indbyggere. Bydelen har ingen industri, en enkelt hovedgade med forretninger og er derudover et beboelsesområde med små parker og store gamle huse med haver. Området blev udviklet i slutningen af 1800-tallet og fungerede som selvstændig kommune fra 1897 til januar 2002. Langt størstedelen af indbyggerne er engelsktalende, og der bor mange børnefamilier.

\section{Montreals bystruktur - før og nu}

Ligesom mange andre byer har Montreal været vidne til store forandringer de seneste 150 år. Ikke alene er den vokset i areal og indbyggertal, den har også undergået væsentlige ændringer i beboersammensætning og status - ændringer, som påvirker forestillinger om byen den dag i dag. I takt med byens ekspansion i slutningen af 1800-tallet, hvor et stadig større område af øen Montreal blev udviklet, opstod der mange mindre kommuner. De fleste af disse kommuner blev imidlertid hurtigt inddraget af Montreal, men der var også nogle, især de mere velhavende med en beliggenhed tæt på centrum, heriblandt Montreal West, der kæmpede imod og dermed formåede at beholde deres status som uafhængig kommune. Da sammenlægningen fandt sted i 2002, bestod øen Montreal af $28^{5}$ uafhængige kommuner af varierende størrelse, og i de sidste 30-40 år er der ikke blevet ændret væsentligt ved disse kommunegrænser.

Siden de første anneksioner i slutningen af 1800-tallet og starten af 1900-tallet har forholdet mellem den centrale kommune Montreal og de omkringliggende kommuner til tider været uharmonisk med en tilbagevendende diskussion om regionalt samarbejde og koordinering. Ideen om en samlet kommune til hele øen blev første gang introduceret i 1960'erne af den daværende borgmester i Montreal, Jean Drapeau, og resulterede i kompromiset om den regionale samarbejdsinstans Montreal Urban Community (MUC). Her tog en forsamling bestående af hele øens borgmestre og lokalpolitikere beslutninger på følgende områder: politi og brandvæsen, offentlig transport, miljøbeskyttelse, ejendomsvurdering og -beskatning og regional planlægning. Hver kommune havde derimod ansvar for byggetilladelser og zoneopdeling i de enkelte områder; kultur, fritid og rekreation; vedligeholdelse af parker og veje, og vigtigst af alt indkrævede hver kommune en kommuneskat og kunne frit disponere over disse indtægter.

Denne struktur er nu blevet ændret med kommunesammenlægningen. Under sloganet „Én ø, én by“ (Une île, une ville), som også blev anvendt af Drapeau i 60'erne, er de 28 kommuner blevet lagt sammen til én. Ud over denne storkommune, som har nogenlunde de samme ansvarsområder som det gamle MUC, er byen blevet delt op i 27 bydelsråd, hvis grænser i mange tilfælde går langs de gamle kommunegrænser. Den tidligere kommune Montreal er dog i kraft af sin størrelse blevet delt ind i mindre områder, og andre små kommuner, såsom Montreal West, udgør nu en bydel sammen med tidligere nabokommuner. I forhold til den gamle struktur er disse bydelsråd ikke længere i en position, hvor de kan indkræve kommuneskat.

Sammenlægningen har også betydet en udskiftning af kommunalpolitikerne. Kort før sammenlægningens ikraftræeden, i november 2001, blev der afholdt valg, hvor den tidligere borgmester i Montreal Pierre Bourque, som var en af arkitekterne bag „én ø, én by“, blev udskiftet med Gerald Tremblay, der ikke i samme omfang støttede ideen. I 
det nye byråd og i de mindre bydelsråd sidder nu mange af de tidligere borgmestre og lokalpolitikere fra omegnskommunerne, som var indædte modstandere af den nye struktur. For en lille kommune som Montreal West lykkedes det imidlertid hverken at få en repræsentation i det centrale byråd eller bydelsrådet. Dette, og mange andre forhold, har forårsaget en stor folkelig modstand.

\section{Nej til Montreal som megaby}

Kommunesammenlægningen i Montreal er som nævnt ikke den eneste i Quebec på dette tidspunkt, og selv om der er tale om meget forskellige byområder, har den folkelige modstand i høj grad været et fælles projekt for quebecere. Der har været samarbejde mellem lokale græsrodsbevægelser fra alle de implicerede byområder, men stærkest har modstanden dog været i Montreal, og en af de største græsrodsbevægelser, Democracité, ${ }^{6}$ blev startet i netop Montreal West. Også de mange lokalpolitikere har kæmpet en indædt kamp. En gruppe borgmestre på øen Montreal forsøgte i løbet af 2001 blandt andet at få erklæret sammenlægningen i strid med loven ud fra principper om sprogrettigheder, men der kom aldrig en retssag ud af det.

Hvad angår byens borgere, har mange opfattet udviklingen af Montreal til en megaby som uforenelig med opretholdelsen af det liv, som de kender og værdsætter, og i Montreal West har denne holdning været særligt udbredt. Her er modstanden i høj grad blevet defineret som en kamp mellem deres lille samfund og den tidligere kommune Montreal, som efter deres mening blev økonomisk og forvaltningsmæssigt misligholdt. Faktisk kan modstanden i høj grad beskrives som et eksempel på en identifikationsproces, hvor kontraster skærpes gennem brug af dikotomier. Disse mekanismer er velkendte og udførligt beskrevet af blandt andre Frederik Barth (1969) og Anthony Cohen (1985), men begrænser sig på ingen måde til etnisk eller national identitet. Dette er sammenlægningsdebatten i Montreal et godt eksempel på. I byen foregår lignende processer blandt folk, som ønsker at definere sig selv som en bestemt slags byboer med en bestemt tilknytning til byen.

\section{Et stabilt lille samfund}

En af de måske væsentligste dikotomier, som sammenlægningsmodstanderne i Montreal West benyttede, blev nævnt gentagne gange under mit feltarbejde. Det var stabilitet versus forandring og usikkerhed. Jeg blev første gang opmærksom på dette modsætningsmantra efter et møde i en af de lokale græsrodsforeninger med navnet Committee for the Preservation of Montreal West. Her blev en strategi for de sidste måneder inden megabyens ikrafttræden diskuteret, og det var tydeligt, at mange var angste for de mulige ændringer, hvilket en af mine informanter bekræftede i en efterfølgende samtale. Jeg fortalte hende om de københavnske bydelsforsøg, som var blevet stemt ned i en folkeafstemning, for således at pointere, at man ikke alle steder nødvendigvis ønsker øget lokalt selvstyre. Hertil svarede hun straks, at de fleste vel er bange for forandringer. For beboerne i Montreal West er fremtiden med en megaby præget af usikkerhed, hvilket forstærker deres ønske om at bevare det, de har, og det, de kender. En anden 
informant sagde direkte: „Vi ved ikke, hvad der kommer til at ske, men vi bliver nødt til at forvente det værste." Denne holdning var ikke enestående for folk i Montreal West, men fik alligevel en meget lokal betydning, for ikke alene synes fremtiden med en megaby usikker, selve følelsen af usikkerhed opfattes af beboerne som en kontrast til deres aktuelle situation i Montreal West. Stabiliteten, der forsvares, er med andre ord ikke generel og udefinerbar, men repræsenterer lige netop deres lille by. Tilsvarende gives usikkerheden et meget konkret udtryk i betegnelsen megaby. Men hvorfor dette fokus på stabilitet og hvilken stabilitet?

I virkeligheden dækker ovenstående modsætning mellem stabilitet og usikkerhed over en endnu stærkere dikotomi, nemlig lille versus stor. Montreal West er som sagt et lille sted med få indbyggere, og i forhold til sammenlægningen kommer denne størrelse til at repræsentere alt det, som beboerne føler sig truet af, hvorfor den også bliver brugt som et forsvar mod forandringer. Således fremstillede mine informanter deres lille by som et smørhul: I Montreal West kender mange hinanden, man ser de samme mennesker på gaden, siger goddag og får en fornemmelse af at være del af et lokalsamfund. Derudover har byen et slags medborgerhus (community center), fra hvilket der afholdes og arrangeres forskellige sociale aktiviteter for både voksne og børn, og som en informant sagde: „Hvis bare man møder op til et lille udsnit af disse aktiviteter, kan man ikke undgå at lære byens andre beboere at kende, for man bliver ved med at se de samme ansigter igen og igen." Men ikke alene kender man mange af de andre beboere, man bekymrer sig også om dem, interesserer sig for dem, og hver sommer holdes flere vejfester, hvor familier går sammen om at lave mad til resten af vejen. Og der er utallige eksempler på, hvordan naboer hjælper hinanden, for det er ,ligesom noget man gør i Montreal West". I tråd hermed er mange beboere involverede i forskelligt frivilligt arbejde, og mange lokale institutioner, såsom voksen- og børnebiblioteket, eksisterer kun i kraft af denne frivillige indsats.

Følelsen af at være et lille samfund, hvor man kender hinanden, bliver yderligere forstærket, ved at man også kender lokalpolitikerne og byens borgmester. De sidder nemlig ikke på et fjernt rådhus, men er beboere ligesom alle andre, som man kan ringe til, hvis man har et problem eller et spørgsmål. Hver måned er der et offentligt møde på rådhuset, hvor byens borgere kan få indsigt i de lokale politiske beslutninger og gøremål. Bortset fra små konflikter om placering af et hundetoilet eller en vej, der er i dårlig stand, er de fleste enige om, at Montreal West er karakteriseret ved det rolige liv uden konflikter. Med beboernes ord: et lille samfund med småproblemer og småpolitik. ${ }^{7}$

At være en lille by kædes således sammen med værdier som nærhed, ro og følelse af sikkerhed, og hvad vigtigere er, disse værdier står i skarp kontrast til beboernes forestillinger om den kommende megaby og den tidligere Montreal kommune. Ikke alene bliver Montreal Wests positive karakteristika fremhævet, men udsigten til en sammenlægning gør forskelle mere udtalte og får en mere fremtrædende plads i folks bevidsthed. ${ }^{8}$ Dermed skal beboernes fremstillinger af Montreal West ikke nødvendigvis ses som et vindue til nogle faktiske forhold, en objektiv virkelighed. Som Michael Jackson pointerer, må sådanne fremstillinger fortolkes som et forsøg på at opnå en følelse af kontrol i en situation, der på mange måder opleves som påtvunget udefra (Jackson 2002:14,16). I Montreal West forsøger beboerne at skabe og udbrede et positivt billede af deres lille by som et modtræk til regeringens lov.

Billedet, som beboerne fremstiller, er imidlertid ikke uden ambivalens. På den ene 
side fremhæver de ved enhver lejlighed, at Montreal West er unik i kraft af sin størrelse, og samtidig frygter de at blive en lille ubetydelig enhed i det nye megaby-landskab „en lille fisk $i$ et stort hav, som ingen lægger mærke til“". Den forventede følelse af afstand i den forenede storby er både fysisk og mental.

Disse bekymringer er udtryk for en bestemt positionering og prioritering $i$ byen. Mens betegnelsen megaby fra provinsregeringens side er et forvaltningsredskab, bliver den for mine informanter et billede på en uheldig udvikling, der går i retning af en mere fragmenteret og bureaukratisk by. Der er også forskel på, om man som borger bor i Montreal West, en anden omegnskommune eller i Montreal Kommune. I den centrale del af Montreal var den folkelige stemning generelt mere positiv over for sammenlægningen, og mange tog politikeres og planlæggeres argumenter om bedre fordeling af byrder og ansvar til sig. Resultatet var, at der blev trukket skarpe modsætninger op mellem byen og forstæderne. For tilhængerne blev modstanden mod sammenlægningen et udtryk for forstædernes tendens til at forskanse sig i deres egne små samfund uden interesse for den større by med dertil påhæftede prædikater som forkælede og asociale, og i stedet advokerede de for en mere retfærdig by. Denne modsætning mellem by og forstad var også et meget dominerende billede i den heftige mediedebat. Et eksempel er en klumme i en af byens gratisaviser The Mirror. Med titlen „I, the megacity“ udtaler kommentatoren, at megabyen vil tvinge forstadsbeboerne væk fra deres små ubetydningsfulde byer og gøre dem til politisk mobiliserede partnere i deres ø og dens anliggender (Gravenor 2001).

Skønt beboerne i Montreal West er imod en sådan opdeling, bidrager de selv til modsætningen ved at forsvare det lille samfund imod ideen om en megaby, og debatten bliver således et konkret eksempel på velkendte diskussioner om forholdet mellem by og forstad samt by og regionalt opland.

I Montreal, ligesom i andre byer, blev det som tidligere nævnt nødvendigt at oprette en regional instans (MUC), der kunne koordinere kommunale indsatser og tjenester, men det har været en tilbagevendende problemstilling, hvem der skal betale hvad, hvor meget og hvordan. Skal en byregion bygges op omkring et magtcenter? Skal den have flere centre? Er det rimeligt, at de mere ressourcestærke forstæder alene tager vare på sig selv og varetager egne interesser? Sammenlægningen i Montreal har med al tydelighed vist disse konflikter.

\section{Det lokale fællesskab som politisk ideal}

Som allerede antydet er modstandskampen i Montreal West omgivet af ambivalens og tvetydighed. Dette bliver endnu tydeligere, hvis man ser på den som en form for politisk kamp. På den ene side er beboerne i Montreal West ganske bevidste om deres rolle som politiske aktører, og på den anden side ønsker de at fremstå upolitiske eller i hvert fald politiske på en bestemt måde. Denne tvetydighed kommer til udtryk i den stærke retorik om lokalt fællesskab, som kan fremstå upolitisk, men som samtidig er et bidrag til den politiske debat og udtryk for en bevidst strategi.

Når jeg tillader mig at kalde mine informanters strategi for bevidst, er det ikke kun, fordi de har et klart mål for øje, men fordi de i deres retorik trækker på velkendte billeder og fortællinger om byen. Dette er et tema i antropologen Ruth Finnegans Tales 
of the City (1998), hvori hun analyserer forskellige byfortællinger og viser, hvorledes disse fortællinger deler væsentlige narrative elementer. I megen byteori er der en sentimental tone, der begræder de lokale fællesskabers udvanding i den moderne storby, der fremstilles som kompleks og fragmentarisk (Finnegan 1998:16; se endvidere Stein 1960). På trods af deres abstrakte karakter appellerer disse teorier til byboere, som i deres forsøg på at forstå og give mening til deres egne liv i byen gør brug af sådanne fortællinger, argumenterer Finnegan (1998). Således bliver Montreal West'ernes „definerende anden" - Montreal Kommune og megabyen - eksponent for netop den fragmenterede og upersonlige storby ude af stand til at give beboere en følelse af tilhørsforhold, mens Montreal West inkarnerer det lokale tilhørsforhold, som ellers opfattes som så sjældent i dag.

I forlængelse af disse fællesskabsforestillinger udtrykker beboerne i Montreal West et ideal om det fælles gode og trækker således på en kommunitaristisk tankegang. Den kommunitaristiske idé om civilsamfundets betydning for det politiske liv er især fremherskende i Nordamerika, hvor principper taget fra livet i en amerikansk small town påføres det politiske liv mere generelt. Tanken er, at fællesskab(sfølelse) skaber solidaritet og ansvar, som er grundstene, hvorpå der kan bygges fælles forestillinger om det etisk gode. Målet er at styrke det nære samfund som en modvægt til det moderne, liberale og individfokuserede samfund. ${ }^{9}$ For mange af mine informanter er Montreal West således et naturligt omdrejningspunkt for engagement og fælles værdier som frivilligt arbejde, naboskab og stærke familiebånd.

Kommunitarismen har ikke et entydigt partipolitisk ståsted, men bruges af folk bredt placeret i det politiske spektrum. Der betyder dog ikke, at der er tale om et upolitisk projekt. Kommunitaristiske ideer indgår som et politisk redskab i mange forskellige sammenhænge, heriblandt altså i mange Montreal West-beboeres kamp mod en kommunesammenlægning dikteret af provinsregeringen. Med promoveringen af det nære samfund ønsker disse beboere at fremstå som en kontrast til storkommunens ,,storpolitik" for således at nedtone det politiske i den tydeligvis politiske kamp. Denne strategi har klare regionale årsager. For at forstå dette aspekt af spillet om den politiserede megaby må vi vende blikket mod Montreals historie og placering i Canadas fransktalende provins.

\section{„Vi er alle montrealere“ - eller er vi?}

I forbindelse med Pierre Bourques lancering af, ,én ø, én by“ blev store bannerplakater slået op i hele byen med ordene Nous sommes tous Montréalais - „Vi er alle montrealere“, og netop denne plakat er et godt udgangspunkt for at forstå de mere lokalspecifikke årsager til, at en betegnelse som megaby opleves som problematisk for folk i Montreal West og andre af de tidligere omegnskommuner.

Blandt montrealere generelt, inklusive mine informanter i Montreal West, hersker der en stolthed over deres by, som de mener adskiller sig væsentligt fra andre canadiske byer ved sin diversitet, tolerance og ikke mindst blanding af engelsk og fransk kultur (se også Radice 2000; Germain \& Rose 2000). Flere af mine informanter føler sig normalt som montrealere frem for Montreal West'ere, og de er glade og stolte over at bo i og være en del af byen. Set i dette lys kan det forekomme underligt, at de samtidig ikke 
billiger bannerne „Vi er alle montrealere“. Men i den aktuelle situation får et sådant slogan et politisk ladet udtryk. Det refererer nemlig ikke kun til den generelle stolthed, men udgør en del af en kampagne for et forenet Montreal. Med andre ord har det stor betydning, hvem der definerer sloganets „,vi“, og hvad „montrealer“ konkret refererer til, for ikke alle har samme erfaringer med, forestillinger om og visioner for byen.

Montreal blev grundlagt af franske kolonister i 1642, men blev erobret af englænderne i 1760, og i mange år dominerede engelsktalende indbyggere byen. Fra midten af 1800tallet til 1960'erne var Montreal Canadas førende forretningscentrum, og folk strømmede til byen for at tage del i den positive udvikling. Langsomt ændrede byens status sig dog i kraft af øget konkurrence fra USA og Toronto, hvilket førte til en stadig stigende arbejdsløshed i 1960'erne og 70'erne. I 80'erne blev mange af byens investeringer flyttet til Toronto, og den har i dag overtaget Montreals position som førende metropol i Canada. Denne udvikling har også haft betydning for beboersammensætning og beboernes indbyrdes relationer. På trods af at de kun i få perioder udgjorde flertallet $\mathrm{i}$ byen, formåede englænderne at beholde den økonomiske magt helt frem til Den Stille Revolution i 1960 'erne. ${ }^{10}$ Siden er byen blevet en overvejende fransktalende by,${ }^{11}$ og med de mange ændringer og økonomiske kriser besluttede mange engelsktalende at flytte fra byen og provinsen i $80^{\prime}$ erne. ${ }^{12}$

Ud over den faldende status, som der er forskellige forklaringer på, vidner byens historie om skiftende magtforhold mellem de fransktalende og de engelsktalende, og denne konflikt bliver i den grad aktualiseret med den nye megaby og „,Vi er alle montrealere"-sloganet. For det første er bannerne skrevet på fransk og af den fransktalende Pierre Bourque. Dertil kommer, at byen i den nye lov 170 åbent bliver erklæret en fransktalende by, hvilket strider mod manges opfattelse af byen som tosproget. Som selvstændig kommune var det indtil 2002 muligt at have officiel tosproglig status, hvis over halvdelen af indbyggerne var ikke-fransktalende, men denne mulighed falder nu væk. Denne omstændighed gør det svært for nogle indbyggere at føle, at „vi alle er montrealere", ikke mindst i Montreal West, hvor de fleste er engelsktalende. Resultatet er, at betegnelsen megaby kommer til at konnotere noget meget forskelligt for forskellige mennesker.

I udgangspunktet deler såvel tilhængere som modstandere af megabyen den opfattelse, at diversiteten er Montreals store aktiv, og at den om nogen by i Canada er indbegrebet af det nationale symbol, en mosaik. Idet diversitet blev et tema i debatten om kommunesammenlægningen, forsvandt denne enighed imidlertid, hvilket var tydeligt ved et lokalt valgmøde i Montreal West i oktober 2001, hvor fortaleren for „én ø, én by“, borgmesterkandidaten Pierre Bourque, var kommet til byen. Et af Pierre Bourques valgslogans var „respekt for diversitet“, men det blev hurtigt mødt med kritiske røster. En kvinde ville vide, hvordan man på den ene side kan proklamere denne respekt, samtidig med at man ikke vil anerkende den diversitet, som de mange kommuner er et eksempel på. Hun mente, at en by som Montreal West er at betragte som et kulturelt fællesskab (cultural community) på lige fod med byens etniske grupper: kinesere, italienere, portugisere osv. I en anden sammenhæng blev denne holdning understøttet af en mand, som ikke længere ville føle sig hjemme i byen, hvis mosaikken - eller minestronesuppen, som han sagde - blev erstattet med en flødesuppe, hvor de enkelte enheder ikke længere stod klart frem. Charles Taylor har argumenteret, at med nye og originale definitioner på identitet søger mange folk i dag at opnå anerkendelse gennem multikulturalisme- 
politikken (Taylor 1993:188), og det er kommunesammenlægningen i Montreal et glimrende eksempel på. Beboerne i Montreal West føler i den grad, at de er en del af et fællesskab, som bygger på en speciel lokal byidentitet, og som burde nyde samme rettigheder og anerkendelse som andre grupper i byen. En ophævelse af kommunegrænsen opleves af beboerne som potentielt ødelæggende for den identitet, som deres beboelsesområde giver dem. Imod denne forestilling står tilhængeres ide om, at ,vi alle er montrealere“, og at det vigtige må være at stå sammen og udvikle byen i en god retning.

Et yderligere problem er imidlertid, at mange er skeptiske over for, hvilken udvikling der er tale om. Er der tale om at gøre Montreal til konkurrencedygtig international by? Er sammenlægningen et udtryk for den interne konkurrence mellem Toronto og Montreal, der synes at herske, siden Montreal måtte lade sin status som førende metropol og derfor: Toronto har for nylig gennemført en sammenlægning og så skal Montreal også? Eller er målet, at Montreal skal være Quebecprovinsens motor? Blandt de engelsktalende i Montreal er der en udbredt forståelse for, at deres by er en selvstændig og unik enhed i provinsen. I modsætning til resten af provinsen mener de, at Montreal er kosmopolitisk og tolerant (Radice 2000), og en sammenkædning mellem megabyplanen og Quebecregeringen opleves derfor af flere årsager som problematisk. Følgende citat fra den lokale avis er et af mange eksempler på følelsesladede vendinger, der udtrykker et ønske om at blive ladt i fred uden regeringens indblanding:

... lige meget hvilke tåbelige ting vores regering gør og vil blive ved med at gøre, vil den ikke ændre min datters følelse af at høre til. Sammenlægningen er en skændsel, men et community er ikke kun bestemt ud fra dets geografiske grænser, det er bestemt af de folk, som bor der - de pragtfulde mennesker i Montreal West.

Men med kommunesammenlægningen har regeringen på ny blandet sig og hermed pustet liv i de potentielle konflikter, der konstant lurer under overfladen.

\section{En regional konflikt}

For mange af mine informanter er Quebecregeringen et symbol på den uoverensstemmelse og modsætning, som de føler mellem det politiske liv og deres eget hverdagsliv. Provinsen er alment kendt for tilbagevendende konfliktfyldte diskussioner om mulig selvstændighed og promovering af det franske sprog i form af diverse sproglove, hvilket gør, at folk generelt oplever politik som konfliktfyldt. I Montreal West mødte jeg utallige eksempler på folk, som ikke til daglig oplever konflikter mellem engelsk- og fransktalende, de ser snarere denne konflikt som en kunstig modsætning skabt af provinsregeringen. Som en informant sagde: „For dem [i provinsregeringen] er det altid mig mod dig ...de forsøger, så snart de kan, at opdele folk i rige og fattige, engelske og franske og nu forstad over for Montreal." Loven om kommunesammenlægning bliver med andre ord betragtet som det sidste af provinsregeringens nye tiltag i en række af mange, som kun har til formål at skabe unødvendig konflikt og differentiering. Hvor tidligere love om begrænsninger af det engelske sprog har været til stor gene og irritation, opleves denne lov som et mere direkte angreb, som rammer mange personligt. Som en informant udtaler: 
Her kom en lov, hvor regeringen sagde: 'Nu trækker vi en bureaukratisk struktur ned over jeres by.' Jeg mener, du vælger at bo i Montreal West, du investerer din tid, penge og fremtid, fordi du kan lide stedet, og pludselig kommer de og siger, at byen er for lille ...her var pludselig noget, hvor jeg ikke havde kontrol, det er en virkelig trussel. Den eneste måde, jeg kan undgå det på, er at flytte, og jeg har ikke lyst til at flytte.

Loven om kommunesammenlægning opfattes altså som forstyrrende for det hverdagsliv, som mange beboere i Montreal West har valgt, og det i større omfang end tidligere love.

Hvad sammenlægningsproblematikken mere konkret betyder for forholdet mellem engelsk- og fransktalende i provinsen, er der ikke entydige svar på. Flere fransktalende beboere i Montreal West er imod sammenlægningen af de samme grunde, som jeg har redegjort for, ${ }^{13}$ andre fransktalende er uden tvivl for sammenlægningen, og så er der de fransktalende, som er imod sammenlægningen, men af helt andre grunde. En fransktalende informant udtrykte således bekymring for, at et forenet Montreal i fremtiden vil betyde dels tættere tilknytning til naboen mod syd, USA, dels mere magt til de engelsktalende. Personligt oplevede jeg, at det var svært at få de fransktalende i Montreal West i tale. De afslog flere gange med bemærkningen om, at det er for politisk at tale om sammenlægningen.

Selv om modstandskampen i princippet er et forsvar for Montreal West og alle dens beboere, trænger sprogproblematikken sig i flere sammenhænge på, og langt størstedelen af de aktive beboere, der er mod sammenlægningen, er da også engelsktalende. Som tidligere beskrevet har mange borgmestre netop gjort brug af engelsktalendes rettigheder som argument for at få erklæret sammenlægningen i strid med loven. En kvindelig informant var blevet udvalgt til at repræsentere Montreal West, hvis sagen kom for retten, og hun var meget ambivalent omkring fokuseringen på sprog. Advokaterne havde flere gange forsøgt at få hende til at komme med udtalelser om engelske rettigheder, men som hun sagde: „Det er ikke kun et spørgsmål om at bevare det engelske“, men fortsatte lidt senere i samtalen: „Problemet omkring engelske rettigheder er helt sikkert en central problemstilling. Jeg ville blive meget trist, hvis jeg en dag ikke kunne gå op til min lokale kiosk og tale mit eget sprog." Det er således kendetegnede for mange beboere i Montreal West, at de ikke ønsker at gøre det til et spørgsmål om fransk versus engelsk, fordi de på den måde bidrager til den differentiering, som de beskylder Quebecregeringen for at stå bag og give næring, ligesom interne uenigheder i byen vil forstyrre og modvirke billedet af et harmonisk lokalt fællesskab. Men ikke desto mindre kommer sprogproblematikken op til overfladen igen og igen, såsom når sindene bliver bragt i kog til et borgermøde på grund af et nyt skilt uden for rådhuset $\mathrm{i}$ forbindelse med kommunevalget, hvor Montreal West er skrevet Montréal Ouest.

I lang tid har hverdagen gået sin vante gang i Montreal West, men loven om en kommunesammenlægning tvinger folk til at tage stilling til Montreals og Quebecs fremtid, og på dette niveau bidrager sammenlægningen uden tvivl til en styrkelse af den fransk-engelske konflikt. Som ofte før i Quebec bliver politik et vilkår, som folk ikke kan undgå.

Idet forskelle og uenigheder ekspliciteres, bidrager politiseringen også til at give nyt liv til den regionalisme, som ifølge flere forskere synes at karakterisere Canada (Frye 1982; Lustiger-Thaler 1994; Mackey 1999). I sin bog om national identitet i Canada skriver antropologen Eva Mackey (1999), at Canada, som følge af engelsk og ameri- 
kansk kulturimperialisme, lider af manglende identitets- og kontrolfølelse. Dette understøttes af den canadiske litterat Northrop Frye, der følgelig karakteriserer Canada som en nation af ,solitudes“ - enlige enheder, hvor der overalt findes separatistiske følelser (Frye i Osborne 1988:173). Selv om disse følelser først og fremmest forbindes med Quebecprovinsen, ${ }^{14}$ kan de også ses som et generelt træk ved Canada. Når folk i en lille kommune som Montreal West er truet på deres overlevelse som selvstændig enhed, kommer denne regionalisme op til overfladen - hver en lille del af Canada er om muligt, og ifølge Frye (ibid.), en adskilt og frigjort enhed.

Ligesom politik i Quebec er et vilkår, kan regionalismen i Canada betragtes som en nedgroet praksis, en måde at være canadier på. Denne regionalisme er nært knyttet til og forstærkes i kraft af ideen om Canada som en mosaik, hvor alle dele skal stå tydeligt frem. Mit materiale er et eksempel på, at der trækkes på disse forståelser i vidt forskellige sammenhænge, og at denne regionalisme snart foregår på ét niveau, snart på et andet. Det betyder dog ikke, at der ikke er uenigheder forbundet med en sådan praksis om, hvorvidt man skal fokusere på helheden eller mindre definerede enheder samt en række andre dilemmaer.

I Montreal West ønsker de at bevare deres lille enhed, men ønsker ikke at bidrage til „dig mod mig"-tendensen i Quebec. De ønsker at være (og føler sig som) en del af Montreal, men ønsker ikke at leve i det politiserede klima, som megabyen repræsenterer. Uden at løse disse dilemmaer vælger de at forsvare deres lille by, som med stabilitet, nærhed, fælles værdier og fællesskabsfølelse fremstår som et tiltrængt modstykke til Quebecpolitikken og megabyen.

\section{Konklusion}

Kommunesammenlægninger og de konflikter, der er forbundet hermed, handler ikke alene handler om økonomi, effektivisering og forvaltning, om end disse aspekter spiller en vigtig rolle for den politiske debat og motivation. Sammenlægningen i Montreal er et eksempel på, at der udspiller sig et væsentligt politisk spil mellem de politikere, der står bag planen, og byens borgere. Dette er ikke mindst tydeligt i den lille kommune Montreal West, hvor kontrasten til en fremtid i megabyen synes stor. Dette eksempel har anskueliggjort diskussioner af mere generel bypolitisk art, såsom modsætningerne mellem lille og stor, forstad og by, men har samtidig vist, hvorledes disse diskussioner indskriver sig i den regionale kontekst. Dette medfører, at ikke alle artiklens indsigter er direkte anvendelige $i$ en analyse af kommunesammenlægninger generelt. Alle byer har hver deres historier, hver deres specifikke problemstillinger og er indføjet i hver deres regionale/nationale kontekst, som nøje må vurderes for at forstå konsekvenserne af og reaktionerne på specifikke sammenlægninger.

I Montreal West træder de sociale og symbolske aspekter ved kommunegrænsen for alvor frem, idet blikket vendes mod en diskussion af Montreals placering i Quebecprovinsen og de særlige problemstillinger vedrørende sprog og forholdet mellem engelsk og fransk, som det indebærer. Ligeledes kan den canadiske idé om regionalisme bidrage til en forståelse af modstandskampen i Montreal West. I en sammenlægningsproces bliver forskelle mellem de enkelte enheder fremhævet og måske forstærket, men det betyder ikke, at disse forskelle er ubetydelige. De viser derimod, at man ikke kan 
adskille den kommunale struktur fra beboeres abstrakte følelser af hjem. De forskellige problemstillinger påvirker gensidigt hinanden, og eksemplet Montreal viser, at det $\mathrm{i}$ mindre eller højere grad er latente følelser og uenigheder, der bliver manifesteret og konkretiseret i kraft af sammenlægningsprocessen. En analyse af sådanne latente følelser er derfor ikke uvæsentlig, hvis man vil sikre en effektiv sammenlægning uden alvorlige konflikter.

\section{Noter}

1. Øen Montreal udgjorde før sammenlægningen den centrale del af Montreal Metropolitan Region og havde en befolkning på 1,8 millioner, heraf cirka halvdelen i byens kerne (the City of Montreal). Lov 170 indebar desuden sammenlægninger i fire andre byområder, heriblandt et forstadsområde syd for Montreal og i Quebec City.

2. Foruden Danmark har man eksempelvis i Berlin i begyndelsen af det nye årtusinde lagt flere af de mindre bydelskommuner (Bezirke) sammen, så de nu udgør større enheder.

3. Foreløbig er der truffet beslutning om sammenlægninger på Langeland/Ærø og Bornholm. Sidstnævnte har allerede gjort sine spæde erfaringer, siden sammenlægningen trådte i kraft 1. januar 2003. Desuden arbejder en strukturkommission på en større reform, der måske vil betyde afvikling af de danske amter i den form, som de har i dag.

4. Politologen Andrew Sancton har skrevet omfattende om kommunesammenlægninger og lægger i bogen Merger Mania ikke skjul på sin kritiske holdning over for tendensen i Canada. Bogen er en bestillingsopgave fra en af de mest synlige kommuner i modstandskampen i Montreal - Westmount.

5. Hvilket er ret mange taget i betragtning, at der er tale om et areal på blot $494 \mathrm{~km}^{2}$.

6. „Democracité“ er en sammentrækning af demokrati og by.

7. For en mere uddybende analyse af betydningen af dette lokalsamfund og ideen om et lokalt fællesskab, se Kielgast (2003).

8. Dette var mine informanter ikke blege for at indrømme. Foreksempel fik jeg helt i starten at vide, at dette var en meget speciel periode, hvor folk derfor var optaget af at fortælle, hvor godt de havde det, og hvad de eventuelt kunne miste.

9. For en mere uddybende behandling af kommunitarismen, se eksempelvis Amitai Etzioni (1998), Alasdair MacIntyre (1981) og Robert Bellah et al. (1985).

10. Den Stille Revolution i 1960'erne var et opgør med mange års tilbageståenhed og indflydelse fra den katolske kirke, hvor quebecere havde været udeladt fra forretningsdrivelse og højere uddannelse. Med en lille engelsk dominerende elite i provinsen ønskede de fransktalende at få mere indflydelse og magt, samtidig med at flere programmer blev sat i gang med det formål at fremme Quebecs sprog og kultur.

11. De fransktalende udgør i dag ca. $80 \%$ af øens indbyggere, men også formelt er byen blevet fransktalende i kraft af provinsregeringens sproglove. Disse love har sikret fransk som arbejdssprog i byen og udstukket strenge regler for skiltning, som skal være på fransk. Den måske mest kontroversielle lov fastlagde i starten af 1970’erne, at alle børn, som ikke har engelsk som modersmål, skal gå i fransk skole.

12. Ofte omtalt som udvandringen af engelsktalende er denne del af byens historie et særdeles omstridt tema. Mange engelsktalende anklager det usikre politiske klima med separatistbevægelsen for, at så mange forlod byen, mens nogle forskere har påpeget, at det svindende antal engelsktalende i byen kan forklares ud fra lav fødselsrate og en aldrende engelsktalende befolkning. For uddybende behandling af dette spørgsmål, se Radice (2000:32-41). 
13, I mange af øens andre kommuner, hvor flertallet af beboerne er fransktalende, har modstanden været lige så stor, og i græsrodsorganisationen Democracité har engelsk og fransktalende kæmpet side om side mod sammenlægningen.

14. For en uddybende behandling af det nationale projekt i Quebec, se Handler (1988).

\section{Litteratur}

Abu-Lughod, Janet L

1994 From Urban Village to East Village. The Battle for New York's Lower East Side. Cambridge, MA: Blackwell Publishers.

Barth, Frederik

1969 Ethnic Groups and Boundaries: The Social Organization of Cultural Difference. London: George Allen \& Unwin.

Bellah, Robert et al.

1985 Habits of the Heart: Individualism and Commitment in American Life. Berkeley, CA:

University of California Press.

Caldeira, Teresa P.R.

1999 Fortified Enclaves: The New Urban Segregation. I: J. Holston (ed.): Cities and Citizenship. Durham \& London: Duke University Press.

Cohen, Anthony

1985 The Symbolic Construction of Community. London \& New York: Tavistock Publications.

Etzioni, Amitai

1998 Introduction. A Matter of Balance, Rights and Responsibilities. I: A. Etzioni (ed.): The Essential Communitarian Reader. Lanham: Rowman \& Littlefield Publishers.

Frye, Northrop

1982 Divisions on a Ground. Essays on Canadian Culture. Toronto: Anansi.

Germain, Annick \& Damaris Rose

2000 Montréal - The Quest for a Metropolis. Chichester: John Wiley \& Sons Ltd.

Gravenor, Kristian

2001 I, the megacity. Mirror, August 23-August 30:9.

Handler, Richard

1988 Nationalism and the Politics of Culture in Quebec. Madison: University of Wisconsin Press.

Jackson, Michael

2002 The Politics of Storytelling: Violence, Transgression, and Intersubjectivity. København: Museum Tusculanum.

Kielgast, Louise

2003 The Montreal West Story - Claiming Community in the New Mega-City. Specialerække nr. 271, Institut for Antropologi, Københavns Universitet.

Low, Setha M. (ed)

1999 Introduction. Theorizing the City. The New Urban Anthropology Reader. New Jersey: Rutgers University Press.

Lustiger-Thaler, Henri

1994 Local Dialogues and the Search for Community. I: V. Lustiger-Thaler \& V. Amit-Talai (eds.): Urban Lives - Fragmentation and Resistance. Toronto: McClelland \& Stewart Inc.

MacIntyre, Alasdair

After Virtue. Notre Dame, IN: University of Notre Dame Press. 
Mackey, Eva

The House of Difference. Cultural Politics and National Identity in Canada. London \& New York: Routledge.

McDonogh, Gary

1999 Discourses of the City: Policy and Response in Post-Transitional Barcelona.

I: S. Low (ed.): Theorizing the City. The New Urban Anthropology Reader. New Jersey:

Rutgers University Press.

Osborne, Brian

1988 The Iconography of Nationhood in Canadian Art. I: D. Cosgrove \& S. Daniels: The

Iconography of Landscape. Cambridge: Cambridge University Press.

Radice, Martha

2002 Feeling Comfortable? The Urban Experience of Anglo-Montrealers. Québec: Les Presses de l'Université Laval.

Sancton, Andrew

2003 Merger Mania. The Assault On Local Government. Montreal \& Kingston: McGill-Queen's University Press.

Taylor, Charles

1993

Reconciling the Solitudes. Essays on Canadian Federalism and Nationalism. Montreal \&

Kingston: McGill-Queen's University Press.

Weber, Michel \& Lene Sillasen

2001 ØР: Bornholms klemme. Udfordringer og omstillingsbehov. Nyhedsmagasinet Danske Kommuner 5. 